weather ships and upper-air observations from merchant ships); (c) meteorological data processing, including electronic computers; (d) education and training; $(e)$ any other activities related to the planning, establishment and operation of world, regional and national centres under the World Weather Watch not covered by the preceding itoms.

\section{Wellcome Trust Grant for Research in Chemotherapy}

THe Wellcome Trust is to make a grant of $£ 30,000$ to the Sir William Dunn School of Pathology at the University of Oxford. This will meet part of the cost of a new building and provide space for the work of Prof. E. P. Abraham on naturally occurring substances of biological and medical interest. In recent years Prof. Abraham's group has succeeded in isolating cephalosporin $C$, in determining its structure and in showing that a family of compounds of varying biological activity can be obtained from its nucleus. Members of this family promise to be of value in the treatment of penicillin-resistani staphylococcal infections and infections by bacteria from the intestinal tract. The grant will meet part of the cost of constructing an additional floor especially for the use of Prof. Abraham. The building will also house a new Medical Research Council Cellular Immunology Research Unit under the direction of Prof. J. L. Gowans, Henry Dale professor of the Royal Society.

\section{The South African Institute for Medical Research}

Tre annual report of the South African Institute for Medical Research for the year 1962 records in impressive detail the very wide range of research being done by its staff all over South Africa (Johannesburg: South African Institute for Medical Researeh, 1964). Directed by Dr. J. H. S. Gear, the Institute not only conducts detailed research into many fields of medical investigation, but also provides a medical laboratory service for provincial hospitals in every part of South Africa and co-operates with such organizations as the World Health Organization and the U.S. Public Health Service. The report discusses this immense range of beneficent work under six main headings. The first of these is devoted to administration. The second and longest section deals with the work of the Research and Routine Division and covers almost every important field of medical research. The third section deals with the work of the Serum and Vaccine Division on diphtheria, typhoid, Staphylococcus, tetanus, gas gangrene, venoms and anti-venoms. The fourth section discusses the regional medical laboratory service, the fifth deals with research on pneumoconiosis, and the sixth the work of the Poliomyelitis Research Foundation. Like other publications of this kind, the report indicates, to those who read between the lines, not only the incalculable human suffering caused by disease, but also the devotion and industry of the many workers who are dedicating their lives to the alleviation and prevention of this suffering.

\section{The Corrosion and Protection Association}

A Corrosion and Protection Association has been established as an independent and comprehensive organization to embrace all aspects of corrosion and protection science and practice. It is intended that the Association shall serve the interests of all who are engaged in corrosion or protection work, and will not seek to rival existing groups, but rather to supplement them. It will especially strive to bring the latest advances before practising engineers, and its official journal will be Corrosion Science, which, in its new enlarged form, appoaring monthly, will include sections devoted to research papers, present and future practice, and general information. Special terms for subscriptions to the journal will be available to members of the Corrosion and Protection Association. The inaugural meeting of the Association will be held at
2 p.m. on December 30 at the Sir John Cass College, Jewry Street, London, E.C.3. The business will be to adopt a constitution and to elect a Council and officers. Membership (£l per annum) is open to all persons with scientific, technological, practical or commercial interests in corrosion and protection, and further information and forms of application for membership can be obtained from Dr. T. P. Hoar, Department of Metallurgy, Pembroke Street, Cambridge; Prof. 'T. K. Ross, Manchester Colloge of Scienco and Technology; or Dr. L. L. Shreir, Sir John Cass College, Jewry Street, London, E.C.3.

\section{Market Research}

THE latest Library Association Special Subject List (No. 44) is Market Research, by D. C. Fanning (London: The Library Association, 1964. 5s.). A foreword by Viscount Chandos, president of the Market Research Society, shows how capital expenditure on industrial plant and building is generally decided by the results of market research: such factors as high rates of money at a given date are often over-stressed. Since a new plant frequently takes more than three years to bring into production, it is the size and nature of the market three years hence that are the primary considerations, and market research is the examination of these two subjects, projected three years ahead. The book list indicates directories and bibliographies as well as specific books on market research, motivation research, industrial market research, media research, techniques and methods, general text-books and periodicals. It will be useful to all concerned with market research in any of its many forms.

\section{Wild-life Conservation}

Oryx, the journal of the Fauna Preservation Society, continues to improve under its new editor. Conservation news from all parts of the world is well presented in Vol. VII, No. 5, August 1964, and a number of articles deal with special aspects of the subject. The most important is ono by Dr. Fraser Darling on the ethical and technical problems of wild-life conservation, in which he emphasizes that animals and plants exist in an environment which is not merely physical or climatic but biotic and social. Ho gives a reasoned argument on the necessity for the management of wild-life in a world largely claimed by man for his own immediate needs, and shows the importance of controlling the numbers of wild animals in certain circumstances so that they shall not destroy their own environment. He does not, however, point out the obvious conclusion that man himself must control his numbers and bring himself into an ecological balance with his environment.

\section{Clonal Selection Theory of Immunity}

Sir Macfarlane Burnet of the Walter and Eliza Hall Institute of Medical Research, Melbourne, writing in the Australian Journal of Science (vol. 27, July 1964), has described a Darwinian modification to the clonal selection theory of immunity. In the seven years since the clonal selection theory of immunity was first outlined a great deal of research has been concerned with testing its implications. The results can be summarized as being incompatible with the rather rigid form of the theory which postulates that all immunological patterns are normally present at the time of birth. On the other hand, there has been a striking swing away from the classical 'instructive' theories of antibody production to an acceptance of the central point of the clonal selection approach, that the pattern of antibody and of cell reactivity is determined. wholly by genetic processes. The work of Gowans, in particular, has resulted in the establishment of the small lymphocyte as the commonest immunologically competent cell, and there appears now to be no controversy as to the importance of specific stimulation of immunologically 